\title{
Is Self-Fulfillment Essential for Romantic Love? The self-other tension in romantic love
}

\author{
É a Autorrealização essencial para o Amor Romântico?
}

A tensão eu-outro no amor romântico

AARON BEN-ZE'EVa

\begin{abstract}
Two major features of emotions are their personal, interested nature and the centrality of the self-other relation. There seems to be a built-in tension between the two: this is evident, for example, in negative emotions such as envy and hate, where one person has a significant negative attitude toward another. This tension is also obvious in positive emotions, such as schadenfreude, where an individual is pleased about the other's misfortune. Such tension may even be greater in romantic love, where the lover should give special attention and status to the beloved. The tension gains further momentum when we assume that self-fulfillment is an essential feature of romantic relationships. Indeed, it seems that in many low-quality romantic relations, the tension between selffulfillment and the needs of the beloved is real and toxic. However, in enduring profound love, which involves the personal growth of each partner, self-fulfillment is not egoistic, and the tension drives mutual thriving.
\end{abstract}

Keywords: Self-Fulfillment. Romantic Love. Self-Other Tension. Romantic Love.

Resumo

Duas importantes características das emoções são sua natureza pessoal e interessada e a centralidade da relação si próprio-outro. Parece haver uma tensão incorporada entre as duas: isso fica evidente, por exemplo, em emoções negativas como inveja e ira, quando

a Department of Philosophy, University of Haifa, Israel. email: abenzeev@univ.haifa.ac.il 
uma pessoa tem uma atitude negativa significativa em relação a outra. Essa tensão também fica óbvia em emoções positivas, como schadenfreude, quando um indivíduo tem prazer no infortúnio alheio. Essa tensão pode ser ainda maior no amor romântico, onde $o$ amante deve dar atenção e status especiais ao amado. A tensão ganha mais impulso quando assumimos que a autorrealização é uma característica essencial dos relacionamentos românticos. De fato, parece que em muitos relacionamentos românticos de baixa qualidade, a tensão entre a autorrealização e as necessidades do amado é real e tóxica. No entanto, no amor profundo e duradouro, que envolve o crescimento pessoal de cada parceiro, a autorrealização não é egoísta, e a tensão gera prosperidade mútua.

Palavras-chave: Autorrealização. Amor romântico. Tensão si próprio-outro. Amor romântico.

\section{The self-other tension in emotions}

Emotions are personal and interested attitudes. Additionally, emotions are a core means for interacting and communicating with other people. The states, attitudes, and deeds of the other are indeed central in generating emotions. This section briefly describes the personal nature of emotions and the self-other relation in emotions.

\section{The personal nature of emotions}

I have argued that emotions typically occur when we perceive positive or negative significant changes in our personal situation — or in that of those related to us. A positive or negative significant change substantially interrupts or improves a smoothly flowing situation relevant to our concerns. Like burglar alarms going off when an intruder appears, emotions signal that something needs attention. When no attention is needed, the signaling system can be switched off. We respond to the unusual by paying attention to it (Baumeister \& Bratslavsky, 1999; Ben-Ze'ev, 2000, 13-18; BenZe’ev, 2017; Frijda, 2007).

I suggest that emotions are partial in two basic senses: (a) they are focused on a narrow target as on one person or a very few people, and (b) they express a personal and interested perspective and serve to monitor and safeguard our personal concerns. Concerns are matters of interest or importance to us. Emotions serve to monitor and safeguard our personal concerns (Frijda, 2007: Ch. 5; Helm, 2009/2017; Nussbaum, 2001; Taylor, 
1985). The background framework against which emotional events are compared may be described as a personal baseline. We envy those whose standing is evaluated to be higher than our current baseline. The comparative perspective of emotions is then personal: we compare our personal situation to other situations. As Immanuel Kant suggested: it is not things themselves that affect us, but things in their relation to ourselves. The personal baseline determines the way in which we perceive our current, previous, ideal, and "ought" states, as well as these states in other people. Emotions are generated whenever a significant discrepancy between our current personal state, or that of significant others, has occurred (Ben-Ze'ev, 2000, 19-20; Higgins, 1987; Kant, 1963).

The personal and interested nature of emotions gives rise to the claim that emotions are egoistic. However, since emotions are not only about oneself, but also about others who relate to one-family, friends, people in one's country-the personal nature of emotions is not necessarily egoistic. This idea is endorsed by Martha Nussbaum, for example, who argues that the personal nature of emotions does not make them egoistic $(2001,53)$.

\section{The self-other relation in emotions}

In addition to their personal nature, the pivotal role of the self-other relation is further significant characteristic of emotions. The interactions between the self and the other are essential in emotions. The other is typically either the object of emotions or a major concern of them. However, the personal interest of emotions may conflict with the interest of the other.

People are more interesting to people than anything else. The things that people do and say, including the things that we ourselves do and say, are the things that affect us most. Accordingly, Spinoza claims that nothing is more useful to a person than a person (1677, IVp18s). And Thomas Reid characterizes emotions as "principles of actions in man, which have persons for their immediate object, and imply, in their very 
nature, our being well or ill affected to some person, or, at least, to some animated being" (Reid, 1788, 558).

Emotions are typically directed toward agents who are capable of enjoyment and suffering. We can identify ourselves with other agents who are enjoying or suffering, and this induces emotions. Given the great similarity of other human beings to us, we can most easily identify ourselves with them and therefore their enjoyment and suffering have great impact upon us. Emotions may be directed at living creatures such as dogs, cats, or birds. The more the creature is perceived to be similar to human beings, the greater is the emotional intensity toward it. Emotions may also be directed at objects that are actually not agents but have some properties resembling agents or at least are construed to have such properties. Thus, we may feel anger toward our car (Ben-Ze'ev, 2000, 29-31).

\section{Philosophical models of romantic love}

I begin examining the self-other tension in romantic love by briefly describing a few major philosophical models of romantic love that have different approaches to the self-other relation:

(a) The fusion mode, which assumes that the self and the other are fused together in profound romantic love;

(b) The care model, which emphasizes the importance of the other in love;

(c) The dialogue model, which sees the essence of love in the connection between the two lovers.

The fusion model rejects the existence of the self-other tension, arguing that, as we are speaking about one entity, there is in fact no tension here. The care model copes with the self-other tension by assigning significantly greater weight to the other. The dialogue model, which focuses on the shared activities of the lovers, assumes that if these activities are beneficial to both, no tension should exist—or at least the tension can be considerably reduced. 


\section{The fusion model}

In the prevailing fusion theory, where the two lovers form a single entity, as if they were two faces of the same coin, lovers lose their ontological independence. The common desire to be with the beloved becomes a desire to fuse with the beloved, thereby losing one's autonomy and identity.

Already Plato claimed that love is essentially the process of seeking our missing half. The notion of ontological unity, where the two lovers form a single entity, may be associated with the fact that in sexual intercourse, corporal penetration literally fuses the two bodies. However, this fusion makes no sense and is dangerous to a loving relation, since every small movement of one of the lovers may have an exaggerated impact upon the other and the relation itself. The wish to fuse with the beloved is understandable in light of the greatest fear of lovers: separation. However, making the beloved an inseparable part of the lover makes things worse. An adoption of such a conjoined-twins model of intimacy, where every single movement of one of them would require consensus, is contrary to the autonomous nature of lovers. In this model, the more your spouse becomes his/her own person, the more you would feel controlled and torn apart (Bauman, 2003, 17; Schnarch, 1997: 108).

\section{The Care Model}

The popular care model focuses on the beloved's needs (Frankfurt, 1999; Helm, 2010; LaFollette, 1996; Sobel, 1990). Without question, caring is central in romantic love. In this view, genuine love has less to do with the lover's own needs and more to do with a strong concern for the other, accompanied by actual deeds. The care model is most relevant in loving relationships in which the self-other relation involves significant inequality, such as parental love, love of God, or love for someone who is unwell. In these cases, there is nothing wrong with one-sided caring. However, among equals, as in the ideal form of romantic love, one-sided caring (and love) is problematic. 
Caring is an important component in other models of romantic love as well, but in those models, caring is not necessarily the essence of love, and in any case, it is not sufficient for maintaining long-term profound romantic love.

In some extreme versions of this model, reciprocity and the lover's own needs are irrelevant. Thus, Immanuel Levinas (1998) denies the value of reciprocity in love and considers the other to constitute the center and the ultimate preoccupation of the lover's meaningful world. Hence, "the relationship with the other is not symmetrical.. . . At the outset I hardly care what the other is with respect to me, that is his own business; for me, he is above all the one I am responsible for." Love, for Levinas, "is originally without reciprocity, which would risk compromising its gratuitousness or grace or unconditional charity" (Levinas, 1998, 105, 228-29).

In considering the fit of the care model for romantic love, we are not so interested in whether caring is part of love: that is almost always the case. The issue is whether romantic love should be solely defined by reference to caring, or whether other features, such as reciprocity, positive responsivity, joint intrinsic activities, and personal flourishing, are just as important. If this is true, then the care model falls short of fully explaining long-term romantic love (Ben-Ze'ev, 2019, 45-46).

\section{The Dialogue Model}

This model, whose origins can be traced back to Aristotle, has more recently been advanced by Martin Buber (1923/1937) and Angelika Krebs (2015). The model considers the shared connection between the partners as the bedrock of love and views shared emotional states and joint activities as the foundational features of the connection. The connection amplifies the flourishing of the lovers as well as the flourishing of their relationship. Krebs further argues that love is not about each partner having the other as his or her object. Rather, love is about what happens between the partners. Thus, it is "dialogical." Lovers share what is important in their lives. For Krebs, loving somebody involves being (often enough) deeply satisfied with the experiences and activities you share with her. In loving somebody, you enlarge 
yourself through closely interacting with and responding to the other person. We do not thrive in isolation: we are social creatures. In shared activities, the participants are integrated into a (psychological) whole, which is more than the sum total of two individual actions. In such activities, both participants contribute (though not necessarily in the same way or to the same extent), and their contributions fit together to actualize the common good (Krebs, 2014, 2015).

Unlike the care model, the dialogue model emphasizes the autonomy of lovers and their essential equality in establishing the romantic connection. Sharing can occur when one lover is not autonomous, and the relationship is not one of equality. However, such sharing is not deep enough to sustain the development of long-term profound love. The romantic connection expresses the qualities of the romantic partnership that are different and more than the combined value of the lovers' individual characteristics. There is indeed considerable evidence indicating the importance of dialogue in romantic love. In this sense, when it comes to romantic relationships, silence is not golden; couple dialogue and shared activities are the main pillars of a thriving romantic relationship. Thus, research found that shared activities, which are satisfying and stress-free and increased closeness, predicted greater relationship quality concurrently and longitudinally (Girme et al., 2014; Määttä \& Uusiautti, 2013).

\section{Comparing the models}

The tension between the personal nature of emotions and the significant role of the other in emotions is problematic in romantic love, where the beloved is often considered to be of greater value than oneself. An extreme manner of coping with this tension is abolishing the independent status of the lover. This has been done by eliminating the ontological independence of the lover (the fusion model) or the lover's own system of values (an extreme version of the care model). Both views are dangerous, as they involve the loss of the lover's own identity. 
Nevertheless, I believe that each of the above models contains some valid points, even if various formulations of them are too extreme to be plausible. The fusion model is correct in suggesting the existence of some unique, close bond between lovers, but such a bond cannot be that of complete fusion, since in profound love both lovers should enjoy an autonomous status for exercising and fulfilling their different capacities and needs. As the care model suggests, it is clear that the other's interests matter a great deal to me, and I care about these interests as much, or perhaps even more, than I care about what matters to me. However, the beloved is not everything in love-the lover's own thriving is also important. The dialogue model best captures the essence of enduring profound romantic love-the connection between the lovers. As I indicate below, certain types of connection may reduce, or even eliminate, the self-other tension. In any case, the adequacy in this regard of the dialogue model does not mean, as some of its advocates suggest, that love is in the connection between the two lovers. This connection is vital to romantic love, but such love is more than the connection.

\section{Personal flourishing and greater indifference, distance, and flexibility}

The presence of two autonomous agents in romantic love makes their shared interactions central for their personal flourishing, as well as the flourishing of their relationship. Mutual flourishing should consider the given traits and limitations of each partner. Accordingly, extreme behavior, considering only one side, is damaging. Enduring romantic behavior encompasses all sorts of (sometimes even opposing) actions that support a thriving living and loving framework.

The endurance of a romantic relation depends upon finding an optimal balance between opposing, or at least different, traits of each lover. I focus here on three continua expressing the potential tension between the lover and the beloved: sensitivity and indifference, closeness and distance, and rigidity and flexibility. Traditionally, genuine love has been described as involving great sensitivity, profound closeness, and very rigid constraints concerning behavior with other people. However, it seems that 
now, when love and self-fulfillment are considered essential to enduring marriages (or other committed relationships), and when love is all around, limited types of indifference, distance, and flexibility are quite beneficial. Such limitations, which are mainly due to the self-other tension, enable the self-fulfillment and flourishing of both partners.

\section{Sensitivity and indifference}

Sensitivity is often considered one of the primary pillars of a good romantic relationship. While this is certainly true, too much romantic sensitivity can overburden a relationship. A degree of indifference is valuable regarding both the beloved and other people. Some degree of indifference, which expresses mutual trust, is useful when selffulfillment is a fundamental part of an enduring love. Such indifference is also indispensable for enduring romantic love when the environment is permeated with many romantic options.

If you trust your beloved, you will be less likely to worry endlessly about insignificant flaws or inappropriate deeds. Trust requires a degree of indifferencebeing certain that the other acts out of love and good intentions. Certainly, trust has to be gained. However, it ought not to be constantly inspected. We should not be blind, or at least not completely blind, to some of our partner's flaws, but we should also be less sensitive to them by according them minor weight. We cannot conduct our lives properly if we treat everything as equally important; we must have some order of priority. We must learn to be insensitive to some issues and more sensitive to others; otherwise, our mental system will become overwhelmed. Love involves being sensitive to the beloved. Too much sensitivity, however, can ruin love; indiscriminate sensitivity, like indiscriminate freedom, disrupts our order of priorities.

Romantic sensitivity works best within limits. Just as I cannot love everyone, I cannot be sensitive in the same degree and manner to all my beloved's characteristics and behaviors. Romantic sensitivity should focus on the most meaningful and relevant aspects involved in romantic thriving. Without such focus and prioritization, sensitivity 
can become toxic. If we deal with a penny as we would a million dollars, sensitivity overloads us with irrelevant and even destructive noise. Love involves being sensitive to the beloved. However, too much sensitivity, or indiscriminate sensitivity, can destroy love, as it disrupts our normative order of priorities. Adhering to that order requires not merely sensitivity, but also selective indifference (Ben-Ze'ev, 2019, 222-225).

The limited degree of indifference (or sensitivity) should be concerned not merely with one's trusted partner, but also with others. An overly acute sensitivity to other people may detract from the lover's sensitivity and responsibilities toward the beloved. The various degrees of sensitivity and indifference constitute not merely the difference in priority between the lover and the beloved, but also concerning the different priorities attached to the beloved and others.

Research indeed suggests that profound lovers do develop such restricted sensitivity. Thus, Garth Fletcher and colleagues argue that people in highly committed relationships tend to perceive attractive individuals as less appealing than those who are not committed or are single. To defuse the threat of a romantic alternative, individuals in more committed relationships downplay the attractiveness of other potential partners. The authors conclude that certain cognitive biases operate as effective strategies that suppress mate-search processes and strengthen established relationship bonds (Fletcher et al., 2015).

\section{Distance and Closeness}

Another continuum along which the lover-beloved attitudes should be placed is that of closeness and distance. Being temporally and geographically close to your partner is central to romantic love. This centrality is often associated with the idea that the two lovers, as soulmates, merge into a single entity. We have seen, however, that this inappropriate notion of fusion conflicts with the reality in which each lover should enjoy a degree of autonomy. Thus, there must be some geographical and temporal distance in profound love for achieving the optimal romantic closeness. What is the nature and extent of such distance? 
The major function of the distance required in enduring love is enhancing the thriving of each other as well as their relation. The optimal distance should not merely prevent-or least significantly reduce-the tension between the various types of thriving, but it should also enhance each type of thriving. There are no clear rules in this regard, and the optimal distance is best determined by personal and contextual factors.

We can distinguish here between temporal, geographical, and romantic (or more generally, psychological) distance. Romantic closeness, it is commonly thought, is heightened by decreasing temporal and geographical distance. But this is not necessarily so. Up to a point, increasing personal space, which often implies somewhat increasing (temporal and geographical) distance, may increase love and personal flourishing. As the Passenger band nicely puts it, "Only miss the sun when it starts to snow; Only know you love her when you let her go."

Indeed, increasing numbers of romantic couples today live at a geographical distance from each other. Take commuter marriage, for example. A commuter marriage is a relationship between people who are married and intend to remain so, but live apart, usually because of the locations of their jobs, educational demands, or dualcareer pursuits. Modern technologies enable direct and immediate communication that can sustain a continuous, meaningful romantic relationship, despite the distance.

A growing body of research indicates that long-distance relationships often have equal or greater value than close-proximity relationships in promoting and maintaining romantic connections. Several studies have shown that communication in longdistance dating is more intimate, more positive, and less argumentative than in geographically close dating. Openness and positivity - two strategies that involve intimate self-disclosure-are frequently observed in the communication of couples in long-distance relationships, and these add to relationship stability and satisfaction. Commitment and trust are important in all romantic relationships, but in long-distance relationships, they have greater significance, as there are more opportunities for things to happen that will threaten the commitment. Indeed, the percentage of extramarital 
affairs in these relationships is similar, or even lower, than that in standard marriages. Divorce rates also appear to be similar. Whereas in geographically close relationships, coresidence might be considered key to the romantic relationship, in commuter marriage, commitment outweighs coresidence in importance (Ben-Ze'ev, 2019, 226227; Bergen, 2006; Jiang \& Hancock, 2013; Kelmer et al., 2013; Stafford, 2005).

As distance facilitates idealization, people in long-distance relationships tend toward higher levels of optimism and greater idealization of their partner. This could cause them to assess their relationship inaccurately. Thus, couples in commuter marriages consider the likelihood of breaking up within the next year to be lower than do individuals in close-proximity relationships. However, breakup rates turned out to be similar in the two groups. Idealization is often self-fulfilling, and this plays a positive role in enhancing marital quality, which might partly explain the higher marital quality in long-distance relationships (Stafford, 2005).

Since more and more contemporary couples are entering commuting relationships because of work, the time apart might save as many marriages as it destroys. Finding the right physical and emotional distance for the partners is crucial for a satisfactory romantic relationship. Distance has its costs, but a mutually desired distance can minimize the impact of other costs. While many married couples are busy thinking about how to reduce distance, others would like to enlarge it in order to provide more personal space for activities of personal fulfillment. Determining appropriate distance is not easy but doing so eases the enormous burden put on lovers in intimate relationships.

\section{Diversity and flexibility}

The two features discussed above concerning the self-other tension, limited indifference, and greater temporal and geographical distance, have increased the personal space of lovers - making them more autonomous, as well as more capable of amplifying personal flourishing, including self-fulfillment. The third feature also enhances personal space and autonomy, by increasing the flexibility of values and 
norms that are highly relevant to romantic behavior; such an increase permits greater personal diversity.

The constant and fast changes in our modern society make it more difficult for lovers (and people in general) to be happy with their own lot, and hence to achieve personal flourishing. Such achievements require greater flexibility. We can think of flexibility, which is the quality of bending without breaking, as the ability to make changes in a situation that is changing. Stability is highly valuable in romantic relations overall, and in particular in achieving profundity. Interestingly, in our diverse and dynamic environment, it is through flexibility that our enduring romantic relationships remain stable.

Flexibility spans a wide range of human abilities, such as adapting to situational demands, shifting behavioral priorities when needed, maintaining balance among important life areas, and being open and committed to behaviors that fit with deeply held values. These abilities capture the dynamic, fluctuating, and context-specific behaviors of people navigating the challenges of daily life. Rigidity, which indicates a lack of sensitivity to one's context, often points to psychopathology. Healthy people can manage themselves in the uncertain, unpredictable world around them, where novelty and change are the norm rather than the exception (Kashdan \& Rottenberg, 2010).

Romantic flexibility echoes the above features: adapting to situational demands, shifting priorities, and maintaining a delicate balance between life, love, and sexual needs. Romantic flexibility, which involves bending some rigid rules, can prevent romantic relationships from breaking. It is easier to draw clear romantic (and other) boundaries than to keep them. Although normative boundaries are supposed to guide our behavior, reality is rather complicated.

What constitutes romantic flourishing varies considerably, depending on personal and contextual features. People use specific rules to help them cope with their chaotic romantic environment, but there is no golden rule to tell us what constitutes a flourishing, lasting romantic relationships. Extreme romantic flexibility, in which we 
try every such alternative, is contrary to the values relating to who we are. However, extreme rigidity is likely to break us (Ben-Ze'ev, 2019).

\section{Personal flourishing in current romantic environment}

The above three features concerning the self-other tension, that is, limited indifference, greater temporal and geographical distance, and more flexibility and diversity, have a significant impact on the self-other relation in enduring romantic love. I will focus on their impact on the following topics: (a) the nature of marriage (and other long-term committed relations), (b) the feasibility of being satisfied with a goodenough partner, and (c) the current romantic abundance.

\section{Marriage and self-fulfillment}

For most of human history, marriage was a practical arrangement designed to enable the couple to meet their basic survival and social needs. Passionate love had precious little to do with it. Stephanie Coontz shows that this ideal emerged only about 200 years ago: "People have always fallen in love, and throughout the ages many couples have loved each other deeply. But only rarely in history has love been seen as the main reason for getting married." She observes that "in many cultures, love has been seen as a desirable outcome of marriage, but not as a good reason for getting married in the first place." (Coontz, 2005, 15, 18).

To the aforementioned marriage types-pragmatic and loved-based-Eli Finkel adds a third type: personal fulfillment ("self-expressive") marriage, which in his view developed in the United States around 1965. Finkel argues that during the pragmatic era, the primary functions of marriage revolved around the fulfillment of lower needs (such as water, food, and physical, psychological, and economic security); during the love-based era, it centered on midlevel needs (such as romantic love), while the self-expressive era emphasized higher needs (such as self-actualization) (Finkel, 2017; Finkel et al., 2014). 
Finkel (2017) suggests that in self-fulfilling marriages, we do not merely want our spouses to meet our needs, but we want to meet their needs as well. Mutual support is crucial in love and marriage. In such marriages, our spouses develop deep understanding of our authentic selves. Accordingly, they often perceive us as better than we really are. Indeed, we are happiest when our partner views us with a blend of accuracy and idealization (Ben-Ze'ev \& Goussinsky, 2008). Time plays a crucial role in thriving through marriage (and other committed relationships). Finally, there is no shame in pursuing a "good enough marriage." We may aim high in our ideal marriage, but we should have the ability to be satisfied with less than perfect marriages. Constant comparison is lethal to thriving marriages (Finkel, 2017). Accordingly, we should be careful not to give the comparison with the other too much weight.

Research has demonstrated that when a close romantic partner sees and acts toward you in a manner that matches your ideal self, you move nearer toward that self. This has been termed "the Michelangelo Phenomenon." Just as Michelangelo saw his process of sculpting as releasing the ideal forms hidden in the marble, our romantic partners "sculpt" us in light of our ideal self. Close partners sculpt one another in a manner that brings each individual closer to his or her ideal self, thus bringing out the best in each other and making both flourishing while fulfilling their basic values. In such relationships, we see personal growth and flourishing in statements like "I'm a better person when I am with her" (Drigotas, 2002).

\section{Good-enough partner}

The greater personal space and self-fulfillment of lovers has supported an interesting phenomenon: the increasing readiness to accept a good-enough partner, rather than the perfect prince. The greater personal thriving one can get now within the relation decreases the burden of one's partner to fulfill everything the lover needs. Love is not everything you need, and it is often the case that your partner cannot fulfill all other things you need in addition to love. Accepting a good-enough partner expresses greater freedom for lovers to choose their partner only in light of a few good 
qualities of the partner, and not in light of the proximity to the perfect ideal partner. This actually may increase the personal flourishing of both partners.

In romantic compromise, you have settled for less than your dreamed-about romantic partner. The question is, how much "less" can your partner be and still be a sufficiently good partner? This is a complex issue, as someone who initially seems barely good enough can turn out to be the most suitable partner. "Enough" can be considered "as much as necessary." Ideal love, however, seems to be about getting much more than that. In ideal love, enough is not enough, and you can't get enough of your partner - the better she is, the more you want of her. Nevertheless, some people are not fortunate enough to have even a good-enough partner- they might merely have a "just- enough" partner or a "barely enough" partner. Consequently, many people settle for a romantic partner who is no good for them at all.

Herbert Simon combined the words "satisfy" and "suffice" and came up with "satisfice," a term used to express an adequate solution rather than one that maximizes utility. A "satisficing" solution can be the best choice when we take into account the cost of looking for alternatives. In Simon's view, since the human capacity for knowledge is so limited, we would do well to take a realistic approach to seeking optimal solutions, which are not necessarily those that maximize their possible gains. Simon's considerations are relevant to the romantic realm, in which there are further complications concerning our inability to predict the partner's attitude in the long term, as well as our response to that attitude. This makes finding a good-enough partner even more important.

Relevant to the romantic realm is also Harry Frankfurt's (1987) rejection of the "doctrine of economic egalitarianism," which states that it is desirable for everyone to have the same amount of income and wealth. In his view, termed the "doctrine of sufficiency," what is morally important is that everyone should have enough. When following (economic) egalitarianism, people focus their attention on what others have, rather than on what is intrinsically valuable for them. For Frankfurt, being content is a matter of one's attitude toward what she has and not toward what others have. 
It seems that the more satisfied we are with our own situation and activities, the more we tend to be happy with a good- enough partner, as we would not expect Mr. Right to fulfill all our needs - some of them we have fulfilled by ourselves. Thus, one survey found that women with PhDs are twice as likely to settle for Mr. Good- Enough as women with a high school education (The survey was done by the site Make Friends Online, November 27, 2007.)

There are important differences between having what someone else has and having enough. In the former, one makes a superficial comparison to others who might be very different from you, and thus what they have is irrelevant. In the latter, it is one's own attitude that is important, and the satisfaction gained comes primarily from within. Although we cannot avoid making comparisons with others, what counts most in romantic love is the flourishing of our own, unique connection. When we think of our partner as good enough, we realize what is most valuable for us. This does not mean that people should not aim at increasing the profundity of their romantic relationship, but that such improvement will mainly relate to developing the connection with our current, good-enough partner (Ben-Ze'ev, 2019).

\section{Romantic abundance}

The willingness to accept a good-enough partner decreases the self-other tension and increases the likelihood that lovers will stay together. However, the greater diversity and flexibility, combined with increasing romantic options, act against enduring romantic relationships. Romantic abundance increases the self-other tension, as the lover's commitment is likely to be reduced, and the other's status as a beloved partner is less stable.

The greater romantic options may be seen as increasing people's self-fulfillment since they can choose the best of the many available options. However, Richard Thaler and Cass Sunstein (2009) have shown that the popular assumption that you can never be made worse off by having more choices because you can always turn some of them down, is wrong. This assumption, they argue, fails to take into account self-control, 
temptation, and the conflict between short-term desires and long- term welfare. Similarly, Barry Schwartz (2004) points out that people's unending desire for more leads to general dissatisfaction and reduces their sense of well-being. Thaler and Sunstein (2009) criticize the wish to have more mainly because it tends to privilege many superficial, short-term desires and ignore our fewer, profound long-terms needs. Both are powerful criticisms.

Romantic abundance further increases the self-other tension, as it increases instability in a given relationship. Although in circumstances of romantic abundance, a lover may come across a "better" partner, it will be much harder to maintain and develop their bond, as the alluring options are always all around. In this case, greater self-fulfillment of all types of desires, including the superficial ones, may prevent profundity, calmness, and trust in the relation.

\section{Giving, receiving, and personal flourishing}

A basic assumption underlying the assumed self-other tension in romantic love is that since resources are limited, there can be a conflict between the self and the other concerning these resources. Time is a good example. As everyone's time is limited, one may assume that the more time we invest in our personal flourishing, the less time we have for our beloved. No doubt, this assumption is adequate in many circumstances, giving some support to the self-other tension.

There are, however, cases in which the self-other conflict does not exist. Happiness is such an example. Thus, Buddha claimed that "Thousands of candles can be lit from a single candle, and the life of the candle will not be shortened. Happiness is never reduced by being shared." Compatible with this claim, Barbara Fredrickson (2013) argues that positive emotions such as happiness and love broaden people's momentary thought-action repertoire, which in turn serves to build their enduring personal resources, ranging from physical and intellectual strengths to social and psychological capabilities. Similarly, if Francis of Assisi is right in his claim that "For it 
is in giving that we receive," then the competitive model is inadequate, at least in some circumstances of romantic love.

Cases in which positive emotions increase the overall flourishing of all parties are crucial for resolving the self-other tension. This may somewhat diminish the problematic nature of the romantic abundance. One reason is that it is no longer assumed that one partner can fulfill all the needs of the lover. Moreover, the romantic abundance can be beneficial for both partners.

\section{Concluding remarks}

I have claimed that the authentic personal concern of lovers differs from egoism. I have supported this claim by indicating that the essence of romantic love consists of caring and sharing, which are the opposite of egoism. The introduction of self-fulfillment into marriage is compatible with these considerations, as self-fulfillment is essential for bringing out the best in each partner, and hence supporting enduring, profound love.

Personal fulfillment is not self-centeredness. Attempting to nurture your capacities and genuine needs is not egocentric. In romantic love, your flourishing enhances, rather than opposes, the flourishing of your partner, as well as your joint togetherness. Unlike fleeting pleasure, which is typically an immediately rewarding, brief, egoistic experience, profound personal satisfaction, which is a part of one's overall flourishing, includes the flourishing of those close to you. If personal fulfillment refers merely to feeling good, then it will certainly conflict with the partner's well-being. However, if personal fulfillment refers to one's flourishing (eudemonia), then it also includes the ability to love and care about those who love us (as well as other people). Our romantic partners strongly influence how successful we are in our efforts to grow toward our authentic and ideal self, thereby by bringing out the best in us.

I have suggested a few directions in reducing the self-other tension, namely, limited indifference, greater temporal and geographical distance, and more flexibility and diversity. I also have pointed out a few areas in which these directions have a 
significant impact: the nature of marriage (and other long-term committed relations), the feasibility of being satisfied with a good-enough partner, and the abundance of romantic options.

Combining all these together creates what can be characterized (borrowing an expression of Charles Dickens) as "the best and worst time" for lovers. It is the best time as love is always in the air: everywhere you look, every sight and every sound, indicates that love is all around. Finding love is easier not merely because of the abundance of romantic options, but also because one need not engage in a futile search for the perfect ideal person, as finding a good enough partner is good enough. And, it is the worst time for lovers, since in our current speedy society it is difficult for lovers to develop and maintain enduring, profound love.

There is no magic way to remain only with the good times, as there is no formula for love. However, significant steps toward improving the life of lovers could achieve an optimal balance between the various complex features of romantic love.

\section{References}

Bauman, Z. (2003). Liquid love. Cambridge: Polity Press.

Baumeister, R. F., \& Bratslavsky, E. (1999). Passion, intimacy, and time: Passionate love as a function of change in intimacy, Personality and Social Psychology Review, 3, 49-67.

Ben-Ze'ev, A. (2000). The subtlety of emotions. Cambridge, Ma.: MIT Press.

Ben-Ze'ev, A. (2017). The thing called emotion: A subtle perspective. In A. Ben-Ze'ev \& A. Krebs (eds.), Philosophy of emotions, Vol. I., 112-137.

Ben-Ze'ev, A. (2019). The arc of love: How our romantic lives change over time. Chicago: University of Chicago Press.

Ben-Ze'ev, A., \& Goussinsky, R. (2008). In the name of love: Romantic ideology and its victims. Oxford: Oxford University Press.

Ben-Ze'ev, A., \& Krebs, A. (eds.) (2017). Pbilosophy of emotion, 4 volumes. London: Routledge.

Bergen, K., M., (2006). Women's narratives about commuter marriage. Unpublished doctoral dissertation. University of Nebraska-Lincoln. 
Buber, M. (1923/1937). I and thou. New York: Scribner.

Coontz, S. (2005). Marriage, a history. New York: Viking.

Drigotas, S. M. (2002). The Michelangelo phenomenon and personal well-being. Journal of Personality, 70, 59-77.

Finkel, E. J. (2017). The all-or-nothing marriage: How the best marriages work. Penguin.

Finkel, E. J., Hui, C. M., Carswell, K. L., \& Larson, G. M. (2014). The suffocation of marriage: Climbing Mount Maslow without enough oxygen. Psychological Inquiry, 25, 1-41.

Fletcher, G. J., Simpson, J. A., Campbell, L., \& Overall, N. C. (2015). Pair-bonding, romantic love, and evolution: The curious case of homo sapiens. Perspectives on Psychological Science, 10, 20 36.

Frankfurt, H. G. (1987). Equality as a moral ideal. Ethics, 98, 21-43.

Frankfurt, H., (1999). Autonomy, necessity, and love. In Necessity, Volition, and Love. Cambridge: Cambridge University Press.

Fredrickson, B. L. (2013). Positive emotions broaden and build. Advances in Experimental Social Psychology, 47, 1-53.

Frijda, N. H. (2007). The laws of emotion. Mahwah: Lawrence Erlbaum.

Girme, Y. U., Overall, N. C., \& Faingataa, S. (2014). "Date nights" take two: The maintenance function of shared relationship activities. Personal Relationships, 21, 125-149.

Helm, B. W. (2009/2017) Emotions as evaluative feelings. In A. Ben-Ze'ev \& A. Krebs (eds.) (2017). Philosophy of emotion, Vol. I, 174-188.

Helm, B. W. (2010). Love, friendship, and the self: Intimacy, identification, and the social nature of persons. Oxford: Oxford University Press.

Higgins, E. T. (1987). Self-discrepancy: A theory relating self and affect. Psychological Review, 94, 319-340.

Jiang, L. C. \& Hancock, J. T. (2013). Absence makes the communication grow fonder: Geographic separation, interpersonal media, and intimacy in dating relationships. Journal of Communication, 63, 556-577.

Kant, I. (1963). Lectures on ethics. New York: Harper.

Kashdan, T. B., \& Rottenberg, J. (2010). Psychological flexibility as a fundamental aspect of health. Clinical psychology review, 30, 865-878.

Kelmer, G., Rhoades, G. K., Stanley, S. M., \& Markman, H. J. (2013). Relationship quality, commitment, and stability in long-distance relationships. Family Process, 52, 257-270. 
Krebs, A. (2014). Between I and Thou-On the dialogical nature of love. In C. Maurer, T. Milligan, and K. Pacovská (eds.), Love and its objects. London: Palgrave Macmillan, 7-24.

Krebs, A. (2015). Zwischen Ich und Du. Eine dialogische Philosophie der Liebe. Berlin: Suhrkamp.

LaFollette, H. (1996). Personal relationships. Oxford: Blackwell.

Levinas, E. (1998). On thinking-of-the-other: Entre nous. New York: Columbia University Press.

Määttä, K., \& Uusiautti, S. (2013). Silence is not golden. In Many Faces of Love (pp. 41-51). Rotterdam: SensePublishers.

Nussbaum, M. C. (2001). Upheavals of thought. Cambridge: Cambridge University Press.

Reid, T. (1788). Essays on the active powers of man. In Philosophical Works (edited by W. Hamilton). Hildesheim: Georg Olms.

Schnarch, D. (1997). Passionate marriage: Love, sex, and intimacy in emotionally committed relationships. New York: Norton.

Schwartz, B. (2004). The paradox of choice. New York: HarperCollins.

Simon, H. A. (1979). Rational decision making in business organizations. The American economic review, 69, 493-513.

Sobel, A. (1990). The structure of love, New Haven: Yale University Press.

Spinoza, B. (1677). Ethics. In E. Curley (Ed.), The collected works of Spinoza. Princeton: Princeton University Press (1985).

Stafford, L. (2005). Maintaining long-distance and cross-residential relationships. Mahwah, N.J.: Lawrence Erlbaum.

Taylor, C. (1985/2017). The concept of a person. In A. Ben-Ze'ev \& A. Krebs (eds.), Philosophy of emotion, Vol. I, 42-56.

Thaler, R. H., \& Sunstein, C. R. (2009). Nudge. Penguin Books.

RECEIVED: 08/01/2019

RECEBIDO: 01/08/2019

APPROVED: 09/02/2019

APROVADO: 02/09/2019 